\title{
イヌ上行大動脈中心軸付近の乱流強度
}

\author{
—-Hot-Film 流速計による実測検討—— \\ 山口隆 美*・吉川哲夫* \\ 吉川 昭*。菅原 基 晃*

\section{Turbulence Intensity Measured in the Center of Canine Ascending Aorta with a Hot-Film Anemometer} \\ Takami Yamaguchi*, Tetsuo Yoshikawa*, Sho Kikkawa* \\ and Motoaki SuĞawara*
}

The turbulence intensity near the central axis of the canine ascending aorta was measured with a hot-film anemometer. The cardiac output and the heart rate were controlled arbitrarily by the use of an extracorporeal circulation called open-loop method and of an atrial pacing. Drugs other than anesthetics were not used.

Blood flow velocity waveforms showed highfrequency fluctuations appearing near at the peak systolic velocity and persisting all the way through the deceleration phase of systole. These fluctuations were regarded as turbulence.

We designed a computer method for separating the turbulence from the physiological changes of the blood flow velocity. The mean turbulence intensity was defined as the square root of the time integral of the ensemble average square of the turbulence velocity; the integration interval was the whole deceleration phase of the ensemble average blood flow velocity. The relative mean turbulence intensity was defined as the ratio of the mean turbulence intensity to the time mean sectional average velocity in the aorta. It was constant in most animals regardless of the changes in fluid mechanical parameters. In some animals, however, the relative mean turbulence intensity was dependent upon the peak Reynolds number. The relative mean turbulence intensity positively correlated with the frequency parameter, but the correlation was not so

\footnotetext{
* 東京女子医科大学附属日本心臟血圧研究所 東京都新宿 区市谷河田町 10

* Heart Institute Japan, Tokyo Women's Medical College, Shinjuku-ku, Tokyo

(Received November 27, 1979)
}

strong. The amplitude ratio (ratio of the peak velocity to the mean velocity) failed to make its role clear in the turbulence phenomena in the present experiments.

\section{1.はじめに}

血流が層流から乱流に遷移すると，血液内部および 血液が血管壁に与えるせえ断応力, 血液の混合や物質 拡散の速さなどが大きく増加する，血液内部のせえ断 応力の増加は, 溶血 ${ }^{1)}$, 血栓形成 ${ }^{2)}$, 鎌状赤血球症に おける sickling crisis $^{3)}$ (注1) の原因などになると考え られている. 血管壁が受けるせ்断応力の増加は, 血 管内膜の微小な傷害や, 物質透過性の変化を引きおこ して，動脈硬化症の遠因をなす可能性がある。また， せえ断応力の不規則な変化によって, 粥状硬化症の局 在を説明できるとする実験結果 ${ }^{4}$ は; 乱流に対してむ 適用が可能である. 乱流がむたらす血管壁の振動は, post-stenotic dilatation(注 2 )の発生に不可欠のもので あるとされている5). また，乙の振動は，心雑音特に 駆出性雑音の成因であると考えられ ${ }^{6}$, 乱流の強さと 雑音の強さには，明らかな相関がある7゙.

血管内，乙とに大血管内に，自然の状態や種々の病 的状態で乱流が発生するか否かは，古くから興味がす たれていた. すでに 1952 年, McDonald はウサギの 大動脈に色素を注入して, 乱流が存在することを確か

(注 1) sickling crisis：先天性の異常へモグロビン血症で ある鎌状赤血球症（sickle cell anemia）においては, 通常は正常の形状をしている赤血球が，何らかのきっか けで, いっせいに変形して機能障害を起こすという現象 がある.とれを sickling crisis と呼ぶ.

(注 2) post-stenotic dilatation: 動脈に狭窄が生じた場 合，その下流に内径の拡大した膨大部が生じる現象. 
めているが ${ }^{8)}$ てれに引き続き $\mathrm{X}$ 線映画 ${ }^{91}$ や熱希釈法 ${ }^{10}$ を用いた乱流の研究が行われている. しかし，乙れら の方法では, 乱流の性質について, 定量的研究を遂行 するのに限界があった. 1960 年代の終わりに, Hotfilm 流速計が，医学・生理学的研究に応用されるよう になって, 乱流の本格的な研究が初めて可能になっ た ${ }^{11), 12)}$. Hot-film 流速計を用いた初期の研究では,

乱流は小形の動物に時に見い出される程度とされてい たが，次第に乱流が通常の状態であると ${ }^{13)}$ 考えられる ようになり，その発生の条件などむ，工学的研究と関 連させて検討されるようになった

血管内の流れに類似した流れである円管内の振動流 については，工学的立場から，さまざまな検討がされ

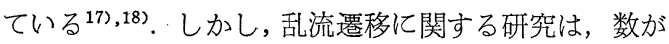
少なく，振動流を定常流より安定であるとする報告が いくつかあるが，生体内とは条件がかなり巽なってい

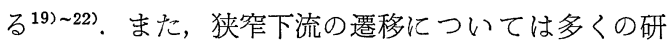
究があり, 安定性は流れの振動数を無次元化した周波 数パラメータとレイノルズ数に依存するとされてい $ろ^{23)}$.

血管内の流れの遷移条件については，血管壁近傍の 不安定性が原因であるとする立場から，最大レイノル ズ数と周波数パラメータのある種の関係が提案されて (る ${ }^{14), 15)}$. しかし，乙机らの研究は，乱流の測定に ついては半定量的であり，広範な生理的条件をカバー していない，また乱流の強さについては，動物および 臨床例での検討があるが77,24)，解析上定量性に厳密さ を欠く.

著者らは, Hot-film 流速計を用い, イヌの上行大動 脈中心軸付近の血流速度を測定し, 結果龙計算機処理 して，大動脈内の乱流を定量的に検討した.

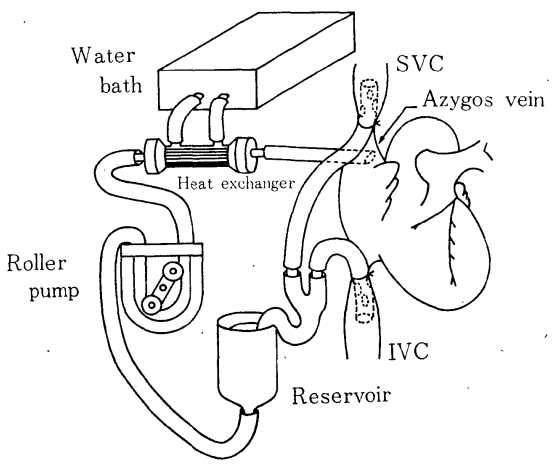

Fig. 1. Experimental setup (open-loop method) SVC: superior vena cava, IVC: inferior vena cava

\section{2. 方法}

\section{1 動物実験}

雑種成犬 13 頭（体重 $12.0 \sim 32.0 \mathrm{~kg}$, 平均 $25.1 \mathrm{~kg}$ ) をペントバルビタール $(25 \mathrm{mg} / \mathrm{kg}$ 体重）静脈内投与 で麻酔し，人工呼吸を行った．胸骨正中切開に左第 3 または第 4 肋間切開を加えて, 開胸した動物に Fig. 1 に示すバイパスを装着した。 これは通常 open-loop 法 と呼ばれるバイパスを改良したあので，上下大静脈か ら脱血し, ポンプ・熱交換器を介して, 奇静脈経由で 右心房へ送血する，乙のバイパスは，心蔵に侵襲を加 えないで装着できる、ローラーポンプは，あらかじめ 流量と回転数を較正した. 右心房の洞結節付近に 10 \%ホルマリン液を注射して, 可及的に心拍数を低下さ せてから心房ペーシング(注3)を行った．乙の設定で は, ローラポンプの回転数により心拍出量を, またぺ ーシングの頻度によって，心拍数をある程度任意に制 御できる.

\section{2 計測}

2.2.1 Hot-film 流 速計

上行大動脈内の血流 速度を測定するのに用 いた Hot-film 流速計 プローブは，円錐先端 を有する直径 $0.5 \mathrm{~mm}$ の針形プローブで, DISA 社製特注品であ る. 流速計本体扔よ びリニアライザは, 同 社製 $55 \mathrm{M} 01$ 型および 55 M 25 型である. Hot-film 流速計は, 恒 温化した回転水槽を用 いて 25$)$ ヘマトクリッ 小值 (注4) と血漿蛋白 濃度の異なるイ又血液 について, 流速と出力

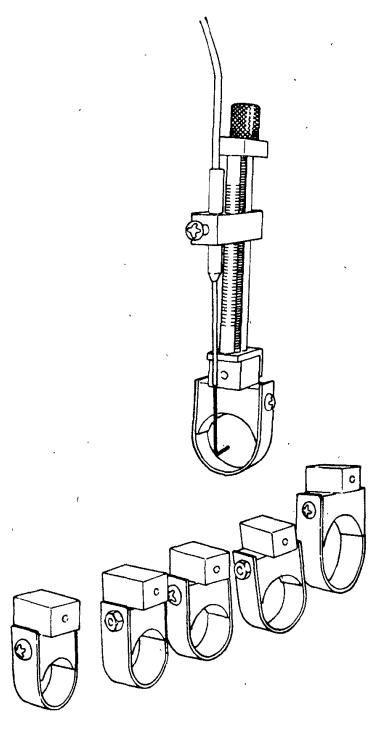

Fig. 2 A needle-type hot-film probe and traverse assembly with exchangeable aortic cuffs

（注 3） 心房ペーシング：心臟の自律的興奮は，心房から心 室へと伝達されるが，とのいずれかに電気的刺激を与え れば，心臓の収縮を起てすととができる(ペーシング). このうち比較的正常に近い興奮順序で刺激するために, 心房（この場合は右心房）に装着した電極からパルスを 与えるのを心房ペーシングという.

(注 4) ヘマトクリット值 (Hematocrit value): 全血 (whole blood) 中に占める赤血球の容積分率. 


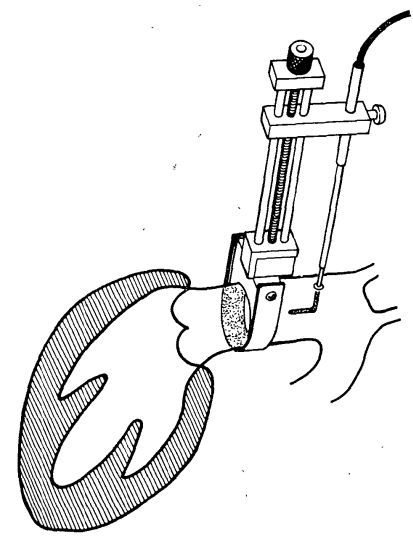

Fig. 3 Scheme of positioning of the hot-film probe in the ascending aorta

電圧の関係をあらかじめ求めた ${ }^{26)}$. 各実験でとにはこ の 2 種のパラメータを测定して較正曲線を計算し，て の曲線汇従う電圧を, 標準電圧源で発生させ, リニア ライザのパラメータを設定した，その誤差は，最大に 見積って数％以内であると考え弓れた ${ }^{26)}$. また，わ れわれの使用した Hot-film 流速計システム全体の周 波数応答は，急速停止流れを用いる方法 ${ }^{26}$ により水中 で実測し，少なくとも約 $4 \mathrm{kHz}$ まで平坦であるとと を確かめた。

露出した上行大動脈の心膜翻転部よりやや上流に, 小さな巾着縫合をおき，その中心を穿刺して，Hotfilm プローブを挿入した．挿入後は止血のために縫合 糸をゆるく締めたが，大動脈壁の変形を最小限度にす るよう注意した．取り付け位置は，大動脈弁加ら直径 の 1.5 2 倍程度下流であると考えられた．そのやや 上流に, Fig. 2 亿示す治具を取り付けた. プローブ

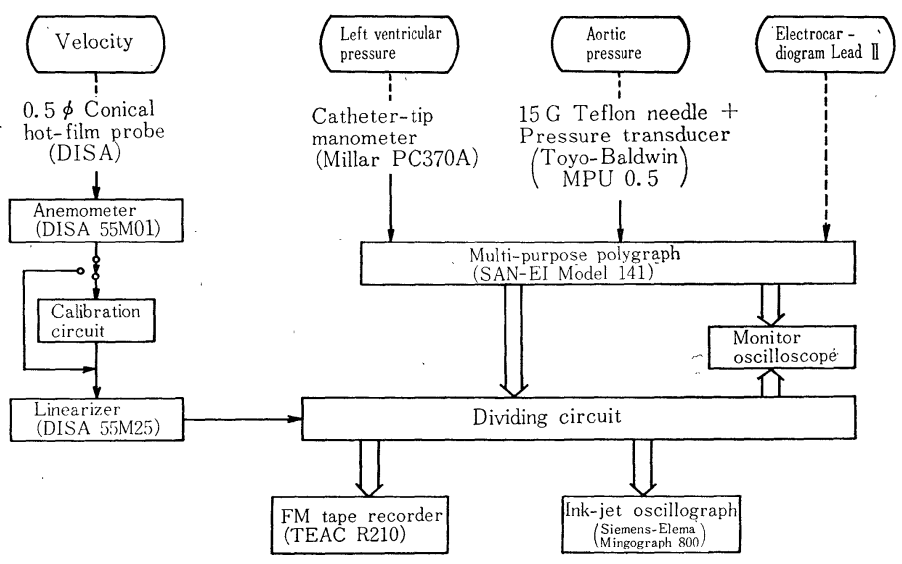

Fig. 4 Block diagram of the instrumentation
をこの治具に固定し，プローブ先端が大動脈の断面内 を走查して, 直径上の任意の点にその位置を $1 \mathrm{~mm}$ 以 下の精度で固定できるょうにした．乙の治具は，大動 脈の直径住合わせて 5 種類のカフを交換するととがで き，また上部の構造の重量は $32 \mathrm{~g}$ であって，大動脈 の拍動性変位に十分追随可能と思われた．このためプ ローブ先端は，大動脈壁に対して相対的に固定されて いるとみなしうる。実験の状況を Fig. 3 亿示す.

Hot-film 流速計の over-heat ratio は，熱による血 液凝固，蛋白変性などを避けるために，約 1.01 (温 度差 $\left.5^{\circ} \mathrm{C}\right)$ とした. 動物の血液は十分ヘパリン化し て, プローブ表面への凝血塊の付着を防ぎ, 温度を適 宜確認しつつ実験を行った.

\section{2 .2 その他の計測}

Fig. 4 亿示すように, 他の生理的パラメータの計 測を行った. 大動脈圧は, $15 \mathrm{G}$ テフロン針を左総頸 動脈から扫入し，東洋ボルドウイン社製 MPU 0.5 型 圧力トランスデューサで測定した．左心室圧は，心尖 部の小切開から挿入したミラー社製 PC $370 \mathrm{~A}$ 型カテ ーテル先端型圧力トランスデューサで測定した. 以上 の計測信号は, 心電図第扛誘導とともに, 三栄測器製 141 型ポリグラフと自作ディバイダを経由して, イン クジェット式オシログラフ (Mingograph 800) と FM データレコーダ（TEAC R 210 型）に記録した. 血 液の粘度は, Brookfield 社製粘度計を用いて, ヘマト クリット值との関係をあらかじめ求めておき，各実験 ごとにはへマトクリット值を測定して粘度はそれから 計算した。

\section{3 解析}

FM データレコーダに記録したデータのうち, Hotfilm 流速計によって得られた血流速度の記録は,

FACOM U-200 型ミニコンで A/D 変 換して, ディジタル磁気テープに収録 した. A/D 変換のサンプリング周波数 は $2 \mathrm{kHz}$ であった。 さらにデータ は, FACOM 230-25 システムで編集 計算処理を行った。

解析の詳細については別に報告し た27)ので結果の表示についてのみ述べ る. 連続な流速データから各心拍ごと に切り出した $u_{l}(t)(l=1,2, \cdots)$ とそ のアンサンブル平均 $\langle u(t)\rangle$ との差 $\tilde{u}_{l}(t)(l=1,2, \cdots)$ を乱流成分とし， そのアンサンブル 2 乗平均の平方根 $\sqrt{\left\langle\tilde{u}^{2}(t)\right\rangle}$ を乱流強度とする. 駆出時 間 $T_{E}$ のうち $\langle u(t)\rangle$ が減速する時間 
に㧍ける〈 $\left.\tilde{u}^{2}(t)\right\rangle$ の時間平均の平方根を平均乱流強度 Iとする.

流速のアンサンブル平均 $\langle u(t)\rangle$ の最大值 $\langle u(t)\rangle_{\max }$ を代表速度とするレイノルズ数（最大レイノルズ数 $\left.R e_{p}\right)$ 之，収縮期にわたる時間平均速度に対するレイ ノルズ数（平均レイノルズ数 $R e_{m}$ ）を次式のごとく定 義する

$$
\begin{aligned}
R e_{p} & =\frac{\langle u(t)\rangle_{\max } \cdot d}{\nu} \\
R e_{m} & =\frac{\frac{1}{T_{E}} \int_{T_{E}}\langle u(t)\rangle d t \cdot d}{\nu}
\end{aligned}
$$

$d$ は大動脈の直径，vは運動粘性係数である．

心拍周期に対応する周波数パラメータ $\alpha$ は, つぎの ように定義する。

$$
\alpha=\frac{d}{2}\left(\frac{\omega}{\nu}\right)^{1 / 2}
$$

$\omega$ は心拍の角周波数で, 心拍数 $n$ に対し

$$
\omega=2 \pi \cdot n / 60
$$

また，振幅比 $\beta$ をつぎのように定義する。

$$
\beta=\frac{\langle u(t)\rangle_{\max }}{u_{\text {mean }}}
$$

$u_{\text {mean }}$ は，体外循環回路の送血量 $F$ （この場合心拍 出量にほぼ等しい）と，大動脈の直径から求めた時間 平均速度である。

$$
u_{\text {mean }}=F /\left(\pi \cdot\left(\frac{d}{2}\right)^{2}\right)
$$

これらの無次元パラメータに刘応して前に定義した 平均乱流強度 $I$ を，上記の $u_{\text {mean }}$ で除した值を，相対 乱流強度 $I^{*}$ とする.すなわち，

$$
I^{*}=I / u_{\text {mean }}
$$

\section{3. 結 果}

実験は各動物について，種々の平均流量 - 心拍数の 組合せのむとに，麻酔剂以外の薬物を使用しないで行 った．血流速度の測定は，上行大動脈の中心軸付近 （中心軸から半径の $\pm 10 \%$ 以内）で行った，Table 1 に 158 件の実験について, 各種の生理的パラメータ, 実験条件の最大值・最小值・平均値および標準偏差を 示す. Table 2 に Hot-film 流速計から得られた測定 值，およびそれをあとに計算した無次元パラメータに ついて同様に示す.

記録の実例を Fig. 5 亿示す。最下段が Hot-film 流 速計を用いて計測した血流速度であるが，立上りか ら最大速度に至る加速期には，速度の不規則な変動は 認められず，最大速度の付近から減速期にかけて，明 らかな流速の不規則変動を認める. との不規則変動

\begin{tabular}{|c|c|c|c|c|}
\hline & $\begin{array}{r}\text { Maxi- } \\
\text { mum }\end{array}$ & $\begin{array}{c}\text { Mini- } \\
\text { mum }\end{array}$ & Mean & S. D. \\
\hline $\begin{array}{l}\text { Peak velocity } \\
\langle u(t)\rangle_{\max }\left(\mathrm{m} \cdot \mathrm{s}^{-1}\right)\end{array}$ & 2. 32 & 0.34 & 1.23 & 0.46 \\
\hline $\begin{array}{l}\text { Mean systolic velocity } \\
\qquad \frac{1}{T_{E}} \int_{T_{E}}\langle u(t)\rangle d t \quad\left(\mathrm{~m} \cdot \mathrm{s}^{-1}\right)\end{array}$ & 1.55 & 0.21 & 0.75 & 0.31 \\
\hline Peak Reynolds number $R e_{p}$ & 9640 & 990 & 4670 & 1810 \\
\hline $\begin{array}{l}\text { Mean systolic Reynolds } \\
\text { number } R e_{m}\end{array}$ & 6560 & 620 & 2860 & 12 \\
\hline Amplitude ratio $\beta$ & 6.98 & 2.49 & 4. 45 & 0.95 \\
\hline $\begin{array}{l}\text { Mean turbulence intensity } I \\
\left(\mathrm{~m} \cdot \mathrm{s}^{-1}\right)\end{array}$ & 0.17 & 0.02 & $0: 07$ & 0.027 \\
\hline $\begin{array}{l}\text { Relative mean turbulence } \\
\text { intensity } I^{*}\end{array}$ & 0.54 & 0.09 & 25 & 0.09 \\
\hline $\begin{array}{l}\text { Mean aortic presure AoP } \\
(\mathrm{kPa})\end{array}$ & 7. 7 & 4.5 & 9.2 & 3.0 \\
\hline
\end{tabular}

Table 1 Physiological parameters of dogs S. D. : standard deviation

\begin{tabular}{l|l|l|l|l|l}
\hline \hline & $\begin{array}{c}\text { Maxi- } \\
\text { mum }\end{array}$ & $\begin{array}{c}\text { Mini- } \\
\text { mum }\end{array}$ & Mean & S. D. \\
\hline Body weight $(\mathrm{kg})$ & 32.0 & 12.0 & 25.1 & 5.55 \\
\hline $\begin{array}{l}\text { Diameter of the ascending } \\
\text { aorta }\left(\times 10^{-2} \mathrm{~m}\right)\end{array}$ & 2.2 & 1.0 & 1.3 & 0.32 \\
\hline \begin{tabular}{l} 
Hematocrit $(\%)$ \\
\hline Mean pump flow $\left(l \cdot \mathrm{min}^{-1}\right)$
\end{tabular} & 3.34 & 1.22 & 2.10 & 0.64 \\
\hline $\begin{array}{l}\text { Normalized cardiac output } \\
\left(l \cdot \text { min }^{-1} \cdot \mathrm{kg}^{-1}\right)\end{array}$ & 0.187 & 0.040 & 0.089 & 0.033 \\
\hline $\begin{array}{l}\text { Time mean sectional } \\
\text { average velocity in the } \\
\left.\text { aorta (m. } \cdot^{-1}\right)\end{array}$ & 0.59 & 0.05 & 0.29 & 0.12 \\
\hline \begin{tabular}{l} 
Heart rate $\left(\right.$ min $\left.^{-1}\right)$ \\
\hline Frequency parameter $\alpha$
\end{tabular} & 18.9 & 10.3 & 14.0 & 2.1 \\
\hline
\end{tabular}

Table 2 Fluid mechanical properties measured with hot-film anemometer and calculated from other parameters

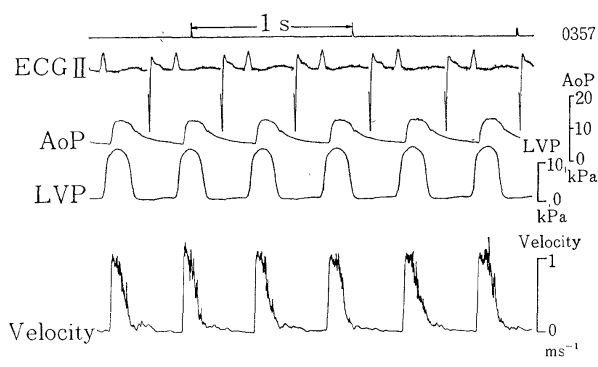

Fig. 5 Representative recordings

ECG II : electrocardiogram lead II, AoP: aortic pressure, LVP: left ventricular pressure, Velocity: blood flow velocity in the ascending aorta measured with hot-film anemometer

は，拡張期の後半には完全に消失しているものと考え られる。このような性質は，すべての記録について同 様であった．Fig. 6 はある個体について，縦軸に平 均乱流強度 $I$ をとり, 横軸にそれぞれ( a ) 平均速度 $u_{\text {mean }} \zeta, \quad(b)$ 最大速度 $\langle u(t)\rangle_{\max }$ をとって関係を示 


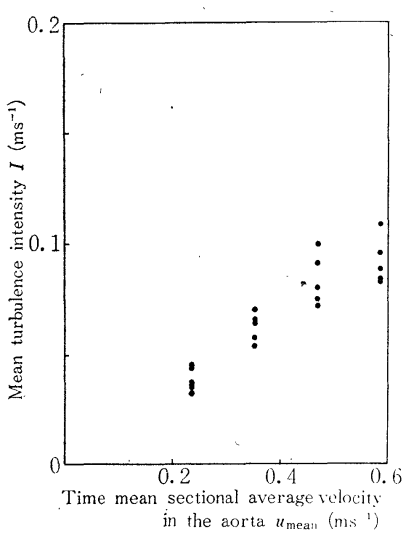

(a)

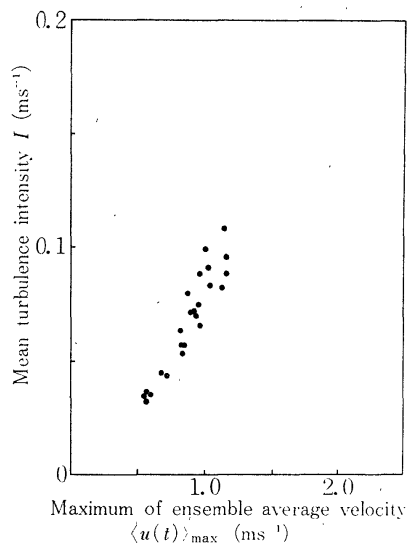

(b)

Fig. 6 Relations for an animal between (a) time average sectional mean velocity in the aorta $u_{\text {mean }}$ and mean turbulence intensity $I$, and (b) maximum of ensemble average blood flow velocity $\langle u(t)\rangle_{\max }$ and mean turbulence intensity $I$

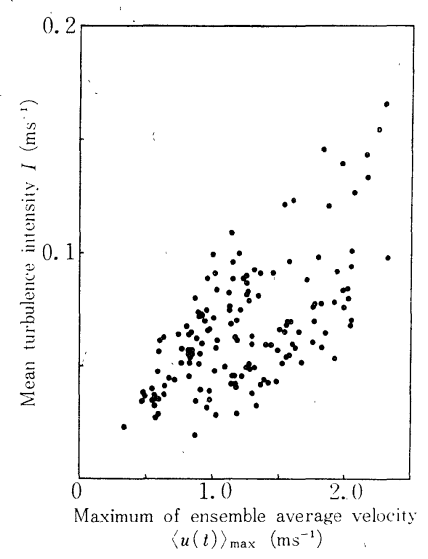

Fig. 7 Relation between the maximum of ensemble average blood flow velocity $\langle u(t)\rangle_{\max }$ and mean turbulence intensity for all the experiments

したもので，両者共にはっきりとした正の直線相関が ある. この関係は，他の動物についても基本的には同 じであった. 実験全体について同様に平均乱流強度と 最大速度の関係を示したのが Fig. 7 で，明らかな正 相関を示す. 最大速度と平均速度では, 平均速度のほ うが全体を通してみれば，個々の動物ごとにより良い 相関係数を与えた. Table 3 に 12 頭の動物について， 平均乱流強度 $I$ と平均速度 $u_{\text {mean }}$ の回帰係数之相関係 数を示す（動物番号 1 のむのは，該当するデータが少 ないので省略した). 相対平均乱流強度 $I^{*}$ は, 動物に よって一定となるすのと，最大レイノルズ数に対して 正相関を示すすのとがあった. 後者の例を Fig. 8 に 示す. 周波数パラメータと振幅比については, 各個体 ごとには十分な範囲をカバーすることができなかった

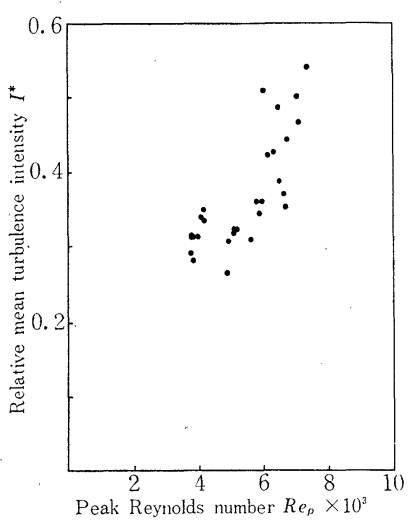

Fig. 8 Relation between the peak Reynolds number $R e_{p}$ and the relative mean turbulence intensity $I^{*}$ for the animal No. 3

Table 3 Coefficient for linear regression and correlation and relative mean turbulence intensity in each animal (the animal No. 1 is excluded because significant number of data is not available)

\begin{tabular}{c|c|c|c|c|c}
$\begin{array}{c}\text { No. } \\
\text { of } \\
\begin{array}{c}\text { ani- } \\
\text { mals }\end{array}\end{array}$ & $\begin{array}{c}\text { Regres- } \\
\text { coef- } \\
\text { sicient }\end{array}$ & $\begin{array}{c}Y \text {-in- } \\
\text { tercept }\end{array}$ & $\begin{array}{c}\text { Cor- } \\
\text { relation } \\
\text { coef- } \\
\text { ficient }\end{array}$ & $\begin{array}{c}I^{*} \\
\text { (mean) }\end{array}$ & $\begin{array}{c}I^{*} \\
\text { (S. D.) } \\
\text { (\% mean) }\end{array}$ \\
\hline 2 & 0.25 & 0.68 & 0.99 & 0.29 & $0.014(4.7)$ \\
3 & 0.56 & -3.9 & 0.91 & 0.37 & $0.073(19.7)$ \\
4 & 0.51 & -3.05 & 0.95 & 0.30 & $0.054(17.8)$ \\
5 & 0.11 & 3.27 & 0.69 & 0.23 & $0.051(22.1)$ \\
6 & 0.10 & 0.37 & 0.97 & 0.11 & $0.004(3.8)$ \\
7 & 0.06 & 2.23 & 0.85 & 0.12 & $0.017(14.0)$ \\
8 & 0.23 & -0.44 & 0.67 & 0.22 & $0.063(29.0)$ \\
9 & 0.15 & 0.47 & 0.92 & 0.17 & $0.020(12.1)$ \\
10 & 0.41 & -3.42 & 0.96 & 0.29 & $0.021(7.2)$ \\
11 & 0.30 & -0.09 & 0.92 & 0.29 & $0.027(9.3)$ \\
12 & 0.17 & -1.88 & 0.99 & 0.12 & $0.013(11.4)$ \\
13 & 0.25 & 0.35 & 0.79 & 0.26 & $0.055(20.9)$ \\
\hline
\end{tabular}

ので，相対平均乱流強度に対する寄与はわからない.

しかし，実験全体を通じてみると，振幅比がある值 以下の場合 (4.13 以下) では，相対平均乱流強度 は, Fig. 9 に示すように，周波数パラメータと弱い 正相関を示すむのと考えられた.

\section{4. 考察}

\section{1 動物実験について}

われわれの用いた実験設定は，心臓の有する特性を 利用し，ペーシングを併用して，平均大動脈血流量を かなり広範に任意に制御することができる。乙れまで 


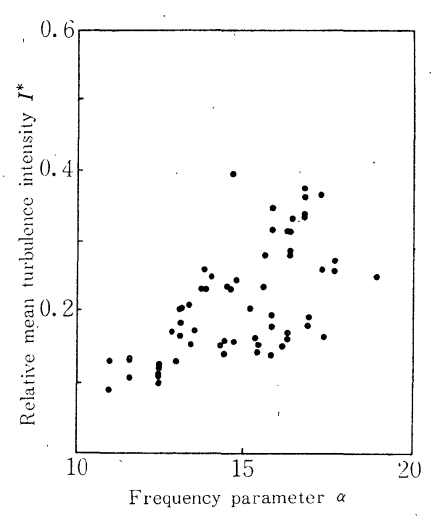

Fig. 9 Relation between the frequency parameter and the relative mean turbulence intensity $I^{*}$ for the experiments in which the amplitude ratios are less than 4.13

の類似の研究に比へ，麻酔の影響・開胸の影響などを より小さくして，ほとんど正常汇近い状態を作り出す ことができたと考えられる. Noble らの結果 ${ }^{28)}$ ，すな わち体重 $\mathrm{kg}$ あたりの心拍出量 $0.09 \mathrm{l} / \mathrm{min} / \mathrm{kg} \sim 0.22$ $l / \mathrm{min} / \mathrm{kg}$, 平均 $0.14 \mathrm{l} / \mathrm{min} / \mathrm{kg}$ に対して，われわれの 実験がカバーした範囲もほぼ同様で，正常覚醒状態と 一致すると思われた。

また，とのような大きな心拍出量の変化を，薬物を 用いないで作り出せるととむこの実験設定の利点で, たとえば isoproterenol のような薬物を用いれば，血 流速度む増加するが，心臓の収縮様式が変わってしま い，比較が難しくなる.

以上のような観点から，われわれの実験は，従来の むのと比べてより生理的に正常な状態に近いと考えら れる.

\section{2 乱流遷移について}

われわれの研究は, 大動脈内の流れの乱流遷移の条 件には，本質的に答えられない，対象は，遷移した乱 流がごのような条件で強さを増すかという問題に絞ら れている。しかし，遷移を規定する条件は，乱流強度 にも直接・間接に影響を及ぽす.

定常な円管内の流れは，レイノルズ数 2000 付近に 臨界点を有する，直円管内の振動流で定常成分が比較 的大きい場合についてのSarpkaya ${ }^{19)}$ の実験的研究に よれば，臨界レイノルズ数は，周波数パラメータと振 幅比の関数であって，周波数パラメータが大きいほど 流れは安定で, 振幅比が特定の值の時に臨界レイノル ズ数がピーク值をとる. ‘かしての研究を含め工学的

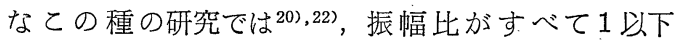
で, 流れ全体の様子には定常流成分の寄与が大きい. また，いわゆる完全振動流は定常成分がないので，振
幅比は無限大となるが, この場合は Hino ら によれば，周波数パラメータが増加すると流れは安定 になる。

これらの研究から, 周波数パラメータが乱流の消長 に大きな役割を果たしていることが明らかである。 ま た振幅比む重要なパラメータである可能性がある.と れらの事実は, 乱れの消長が振動流によって作られる 境界層の厚みに関連しているととを示している，われ われの扱った現象む基本的に同様であると考えられ る. 乙の意味では, 乱机の原因を心室内に求める必要 は200必ずしむないように考えられる。

\section{3 乱流の程度について}

一度不安定となり乱流に遷移した流れを規定する因 子は, 必ずし屯遷移条件亡等しい必要はない. Sarp$\mathrm{kaya}^{19)}$ はその観察の中で，遷移後は主たる流れのエ ネルギーが乱流の程度を決定し, 振動成分の寄与は大 きくないとしている.

われわれの実験条件は，ほぼ完全な間歇流れで振幅 比がはるかに大きく，非定常性が強いにすかかわら ず, 'Fig. 6, Table 3 亿示すように, 平均乱流強度が 平均速度と非常に良い相関を示したととは興味樑い。 流れの平均的な様相を示すと考えられるパラメータが 乱流強度を支配しているというととは，結局心臟加ら 血液が駆出される際の全エネルギーの量が, 乱流の大 きさなどを決定しているとみるてとも可能である.し かし，その分配の比率にあたる相対平均乱流強度が， お打む㱛一定となる個体と，他のパラメータ，最大V イノルズ数と相関を示した個体とが存在したことは， 心拍動などの非定常性の影響が，同じ平均速度に対し てす個体でとに異なるメカニズムを通して出現するて とを示唆しているかもしれない，全体を通して相対平 均乱流強度は，周波数パラメータと弱いながらす正相 関を示したが，振幅比の寄与については確言しうるよ うな関係は見い出せなかった。

\section{5. 結 論}

Hot-film 流速計を用い, イヌに open loop 法のバ イパスを装着して,上行大動脈の血流速度を実測した.

血流速度は加速期には必ず滑らかな変化を示し, 減 速期には，多かれ少なかれ不規則な変動を示したの で，てれを乱流と考えた。

ての乱流成分を，生理的変動となるべく分離して定 量する解析方法を案出し, 時間平均した乱流強度, さ らにてれを平均流速で無次元化した相対平均乱流強度 を計算して，他の無次元パラメータなどと比較した.

平均乱流強度は, 平均流速と各動物個体ごとに良く 
相関した. 相対平均乱流強度は，動物によって一定な むのと, 最大速度を代表速度とするレイノルズ数に正 相関するあのとがあった。

また，周波数パラメータは，相対平均乱流強度と弱 い相関を示したが，振幅比の寄与ははっきりしなかっ た.

本研究の遂行にあたり，つぎの方々にご助言，で協 力を頂いたのでてとに記して心から感謝する.

東京女子医科大学付属日本心臓血王研究所理論外科 谷下一夫博士，同大学付属第二病院循環器外科教授

須磨幸蔵博士，同大学電算室 中川秀二氏，矢島秀樹

氏，東海大学医学部生理学教授 沖野遙博士.

本研究の一部は，つぎに掲げる補助金による，記し

て感謝する.

文部省科学研究費補助金 No. 455025, No. 457342, (財)千代田生命健康開発事 業団社会厚生事業助成金 (昭和 53 年度), 日本心臟財団研究奨励金（昭和 53 年 度).

\section{参 考 文 献}

1) P. L. Blackshear: Mechanical Hemolysis in Flowing Blood, In Biomechanics; Its Foundations and Objectives, edited by Y.C. Fung et al., 501/528, Prentice-Hall (1972)

2) P.D. Stein and H. N. Sabbah: Measured Turbulence and Its Effect on Thrombus Formation, Circ. Res., 35, 608/614 (1974)

3) P.D. Stein, et al.: Augmentation of Sickling Process due to Turbulent Blood Flow, J. Appl. Physiol., 40, 60/66 (1976)

4) R. J. Lutz, et al.: Wall Shear Stress Distribution in Model Canine Artery During Steady Flow, Circ. Res., 41, 391/399 (1977)

5) M. R. Roach: Poststenotic Dilatation in Arteries, In Cardiovascular Fluid Dynamics, edited by D. H. Bergel, 2, 111/139, Academic Press (1972)

6) R.F. Rushmer: Cardiovascular Dynamics, p. 435, W. B. Saunders (1976)

7) H.N. Sabbah and P.D. Stein: Turbulent Blood Flow in Humans-Its Primary Role in the Production of Ejection Murmurs, Circ. Res., 38, 513/525 (1976)

8) D. A. McDonald: The Occurence of Turbulent Flow in the Rabbit Aorta, J. Physiol., 118, 340/347(1952)

9) N-M. Ohlsson: Left Heart and Aortic Blood Flow in the Dog, Acta Radiologica, Suppl. 213, 1/80 (1962)

10) E.D. Freis and W.C. Heath: Hydrodynamics of Aortic Blood Flow, Circ. Res., 14, 105/116 (1963)

11) S.C. Ling, et al.: Application of Heated-Film
Velocity and Shear Probes to Hemodynamic Studies, Circ. Res., 23, 789/801 (1968)

12) B. J. Bellhouse, and F.H. Bellhouse: Thin Film Gauges for the Measurement of Velocity or Skin Friction in Air, Water or Blood, I. Sci. Instrum. (J. Phys. E) 1 (Ser. 2), 1211/1213 (1968)

13) C. G. Caro, et al.: The Mechanics of the Circulation, 330/332, Oxford University Press (1978)

14) R. M. Nerem, et al.: An Experimental Study of the Velocity Distribution and Transition to Turbulence in the Aorta, J. Fluid Mech., 52, 137/160 (1972)

15) R. M. Nerem and W. A. Seed: An in vivo Study of Aortic Flow Disturbance, Cardiovasc. Res., 6, 1/14 (1972)

16) K. H. Parker: Instability in Arterial Blood Flow, In Cardiovascular Flow Dynamics and Measurements, edited by N. H. C. Hwang and N. A. Norman' 633/663, University Park Press (1977)

17) S. Uchida: The Pulsating Viscous Flow Superposed on the Steady Laminar Motion of Incompressible Fluid in a Circular Pipe, Z. A. M. P., 7, $403 / 422$ (1956)

18) J.R. Womersley: Method for the Calculation of Velocity, Rate of Flow and Viscous Drag in Arteries when the Pressure Gradient is Known, J. Physiol., 127, 553/563 (1955)

19) T. Sarpkaya: Experimental Determination of the Critical Reynolds Number for Pulsating Poiseuille Flow, J. Basic Eng. Trans. ASME, 88, 589/598(1966)

20) E. L Yellin: Laminar-Turbulent Transition Process in Pulsatile Flow, Circ. Res. 19, 791/804 (1966)

21) M. Hino, et al.: Experiments on Transition to Turbulence in an Oscillatory Pipe Flow, J. Fluid Mech., 75, 193/207 (1976)

22) D. A. Gilbrech and G.D. Combs: Critical Reynolds Numbers for Incompressible Pulsating Flow in Tubes, In Development in Theoretical and Applied Mechanics, 1, 292/304, Plenum Press (1963)

23) W. Yongchareon and D.F. Young: Initiation of Turbulence in Models of Arterial Stenoses, J. Biomechanics, 12, 185/196 (1979)

24) P.D. Stein and H. N. Sabbah: Turbulent Blood Flow in the Ascending Aorta of Humans with Normal and Diseased Aortic Valve, Circ. Res., 39, 58/65 (1976)

25）山口隆美, 他：Hot-film 流速計の血流速度計測への応 用，医用電子と生体工学，16；130/133 (1978)

26）山口隆美：Hot-film 流速計による血管内の乱流計測の 基礎的検討，医用電子と生体工学， 17，384/385 (1979)

27）山口隆美, 他 : 大動脈内の乱流の解析-Hot-Film 流速 計による実測デー夕解析の方法, 計測自動制御学会論文 集, 16-6 (揭載決定)

28) M. I. M. Noble, et al.: Left Ventricular Ejection in Conscious Dogs; 1 . Measurement and Significance of the Maximum Acceleration of Blood from the Left Ventricle, Circ. Res., 19, 139/147 (1966) 